\title{
PENDEKATAN DAN MODEL PEMBELAJARAN YANG MENGAKTIFKAN SISWA
}

\author{
Abdullah \\ Institut Agama Islam Nurul Jadid Paiton Probolinggo \\ Email : abdul_iainj@yahoo.com
}

\section{Abstrak;}

Guru pada hakekatnya merupakan tenaga kependidikan yang memikul berat tanggung jawab kemanusiaan, khususnya berkaitan dengan proses pendidikan. Pembelajaran merupakan suatu system, yang terdiri dari berbagai komponen yang saling berhubungan satu dengan yang lainnya. Sedangkan belajar adalah proses interaksi terhadap semua situasi yang ada di sekitar individu. Belajar dapat dipandang sebagai proses yang diarahkan kepada tujuan dan proses berbuat melalui berbagai pengalaman. Kegiatan pembelajaran dilakukan oleh dua orang pelaku, yaitu guru dan siswa. Hubungan guru dan siswa harus bersifat dinamis dan syarat dengan makna edukasi. Perilaku guru adalah mengajar dan perilaku siswa adalah belajar. Untuk itu penggunaan pendekatan dan model pembelajaran harus mampu mengaktifkan siswa agar terdapat perubahan pada diri siswa dalam kegiatan belajar.

Keywords; Pendekatan, Model Pembelajaran, Siswa Aktif 


\section{Pendahuluan}

Dalam proses belajar mengajar pemilihan dan penggunaan metode yang tepat dalam menyajikan suatu materi dapat membantu siswa dalam mengetahui serta memahami segala sesuatu yang disajikan guru, sehingga melalui tes hasil belajar dapat diketahui peningkatan prestasi belajar siswa. Melalui pembelajaran yang tepat, siswa diharapkan mampu memahami dan menguasai materi ajar sehingga dapat berguna dalam kehidupan nyata. Belajara akan menjadi lebih efektif apabila kegiatan belajar mengajar sesuai dengan perkembangan intelektual anak (Semiawan, 1990:3). Selain itu juga guru perlu mengenal setiap anak didik dan bakat-bakat khusus yang mereka miliki agar dapat memberikan pengalaman pendidikan yang dibutuhkan oleh masing-masing siswa untuk dapat mengembangkan bakat-bakat mereka secara optimal sesuai dengan tujuan pendidikan.

Permasalahan pendidikan yang kita hadapi sekarang terjadi karena krisis paradigma, yitu adanya kesenjangan atau ketideksesuaian antara tujuan yang ingin dicapai dan paradigm yang digunakan untuk mencapai tujuan tersebut. Paradigm diartikan sebagai pola piker atau cara kerja. Sebagai contoh, jika kehidupanmasa depan menuntut kemampuan memecahkan masalah baru secar inivatif maka apa yang diajarkan kepada siswa di sekolah adalah menghafal atau memecahkan masalah secara lebih baik. Jika masa depan menuntut pola prilaku yang unik dan divergen maka apa yang ditanamkan kepada sisea sekarang adalah pola prilaku yang komformistis dan seragam. Jika masa depan menuntut kemampuan kerja sama dengan sesame teman maka apa yang diajarkan sekarang di sekolah adalah kompetisi atau saingan. (Ardhana, 2001:1)

Belajar pada hakekatnya adalah proses interaksi terhadap semua situasi yang ada di sekitar individu. Belajar dapat dipandang sebagai proses yang diarahkan kepada tujuan dan proses berbuat melalui berbagai pengalaman. Belajar juga nmerupakan proses melihat, mengamati, dan memahami sesuatu (Sudjana, 1989:28).

Pembelajaran merupakan susatu sistem, yang terdiri dari berbagai komponen yang saling berhubungan satu dengan yang lain secara komprehensif. Komponen tersebut meliputi: tujuan, materi, metode, dan evaluasi. Keempat komponen tersebut 
harus diperhatika oleh guru dalam memilih dan menentukan pendekatan, dan modelmodel pembelajaran apa yang akan digunakan dalam kegiatan pembelajaran.

\section{Pendekatan dan model pembelajaran yang menyenangkan mengaktifkan siswa.}

Pendekatan dapat diartikan sebagai titik tolak atau sudut pandang kita terhadap proses pembelajaran. Istilah pendekatan merujuk kepada pandangan tentang terjadinya suatu proses yang sifatnya masih sangat umum. Roy Kellen (1998) mencatat bahwa terdapat dua pendekatan dalam pembelajaran, yaitu pendekatan yang berpusat pada guru (teacher-centered approaches) dan pendekatan yang berpusat pada siswa (student-centered). Pendekatan yang berpusat pada guru menurunkan strategi pembelajaran langsung (direct instruction), pembelajaran deduktif atau pembelajaran ekspositori. Sedangkan, pendekatan pembelajaran yang berpusat pada siswa menurunkan strategi pembelajaran inkuiri dan discoveri serta pembelajaran induktif.

Menurut Sanjaya (2008:127) "Pendekatan dapat dikatakan sebagai titik tolak atau sudut pandang kita terhadap proses pembelajaran. Istilah pendekatan merujuk pada pandangan tentang terjadinya proses yang sifatnya masih sangat umum". Berdasarkan kajian terhadap pendapat ini, maka pendekatan merupakan langkah awal pembentukan suatu ide dalam memandang suatu masalah atau objek kajian, yang akan menentukan arah pelaksanaan ide tersebut untuk menggambarkan perlakuan yang diterapkan terhadap masalah atau objek kajian yang akan ditangani.

Sedangkan model-model pembelajaran yang mengaktifkan biasanya disusun berdasarkan berbagai prinsip atau teori belajar. Para ahli biasanya menyusun model pembelajaran berdasarkan prinsip-prinsip pembelajaran, teori-teori psikologis, analisis system, atau teori-teori lain yang mendukung (Joyce \& Weil,1980). Joyce \& Weil mempelajarai model-model pembelajaran berdasarkan teori belajar yang dikelompokkan menjadi empat model pembelajaran yaitu: (1) model interaksi social, dalam model ini siswa dituntut untuk aktif berinteraksi dengan lingkungan belajarnya; (2) model pemrosesan informasi, menuntut siswa untuk aktif dalam memilih dan mengembangkan materi yang akan dipelajarinya; (3) model personal, yaitu menuntut 
siswa untuk mampu mengeksplorasi dan mengaktualisasikan kemampuannya dalam kegiatan pembelajaran; (4) model mudifikasi tingkah laku, yaitu: siswa harus mampu mengembangkan kemampuannya melalui tugas-tugas belajar, prembentukan prilaku aktif dan manipulasi lingkungan untuk kepentingan belajar.

\section{Jenis-jenis pendekatan pembelajaran}

Variable utama dalam kegiatan pembelajaran adalah guru dan siswa. Tidak akan terjadi kegiatan pembelajaran apabila kedua variable ini tidak ada. Berdasarkan hal tersebut, maka pendekatan dalam pembelajaran secara umum dibagai menjadi dua yaitu pendekatan pembelajaran berorientasi pada guru (teacher centered apporoaches) dan pendekatan pembelajaran berorientasi pada siswa (student centered apporoaches). Hal ini sesuai dengan apa yang dikemukakan oleh Kellen, Roy dalam bukunya yang berjudul Effective teaching Strategis (1998) mengemukakan bahwa ada dua pendekatan dalam kegiatan pembelajran yaitu

a. Pendekatan pembelajaran berorientasi pada guru (teacher centered apporoaches)

Pendekatan pembelajaran berorientasi pada guru yaitu pembelajaran yang menempatkan siswa sebagai objek dalalm belajar dan kegiatan belajar bersifat klasik. Dalam pendekatan ini guru menempatkan diri sebagai orang yang serba tahu dan sebagai satu-satunya sumber belajar.

b. Pendekatan pembelajaran berorientasi pada siswa (Student Centered Approaches)

Pendekatan pembelajaran berorientasi pada siswa adalah pendekatan pembelajaran yang menempatkan siswa sebagai objek belajar dan kegiatan belajar bersifat modern. Pendekatan pembelajaran berorientasi pada siswa, manajemen, dan pengelolaannya ditentukan oleh siswa. Pada pendektan ini siswa memiliki kesempatan yang terbuka untuk melakukan kreativitas dan mengembangkan potensinya melalui aktivitas secara langsung sesuai dengan minat dan keinginannya. dengan menurunkan strategi pembelajaran discovery dan inkuiry serta strategi pembelajaran induktif . 


\section{Pembelajaran Berorientasi Aktivitas Siswa (PBAS)}

Pengembangan pengalaman pembelajaran pada hakekatnya didesain untuk membelajarkan siswa. Dengan demikian maka, dalam mendesain pembelajaran siswa harus ditempatkan sebagai factor utama, dengan kata lain dalam proses mendesain pembelajaran sebaiknya menempatkan siswa sebagai subjek belajar. Oleh sebab itu, setiap siswa harus memiliki pengalaman belajar secara optimal. Dengan kata lain pembelajaran ditekankan atau berorientasi pada aktivitas siswa (PBAS)

\section{a. landasan pembelajaran berorientasi aktivitas siswa}

\section{1) Landasan filosofis}

Pembelajaran berorientasi aktivitas siswa (PBAS) dilandasi oleh filsafat pendidikan progresivisme. Seperti dikemukakan oleh Sadullah (2007:142) dalam bukunya yang berjudul Pengantar Filsafat Pendidikan mengemukakan bahwa:

"Filsafat progresi fberpendapat bahwa pengetahuan yang benar pada masa kini mungkin tidak benar di masa yang akan datang. Karenanya cara terbaik mempersiapkan para siswa untuk suatu masa depan yang tidak diketahui adalah membekali mereka dengan strategi-strategi pemecahan masalah yang memungkinkan mereka mengatasi tantangan-tantangan baru dalam kehidupan dan untuk menemukan kebenaran-kebenaran yang relevan pada saat ini".

Kutipan di atas mengandung makna bahwa pendidikan harus dapat memberikan kemampuan berpikir kritis dan fleksibel, sehingga hasil pendidikan akan menghasilkan individu yang dapat mengatasi berbagai masalah kehidupan yang dihadapi dengan kemampuan merefleksikan pengalaman belajar dalam memecahkan masalah secara mandiri dan tanggung jawab.

Pandangan filsafat progresivisme pendidikan didasarkan pada enam asumsi yaitu:

1) Muatan kurikulum harus diperoleh dari minat dan interest siswa, bukan dari disiplin-disiplin akademin.

2) Pembelajaran dikatakan efektif jika mempertimbangkan interest, minatminat serta kebutuhan-kebutuhan siswa secara menyeluruh dalam dengan domain kognitif, afektif, dan psikomotor. 
3) Pembelajaran pada dasarnya aktif bukan pasif, sehingga guru yang efektif adalah guru yang memberikan siswa pengalaman-pengalaman yang memungkinkan mereka belajar dengan melakukan kegiatan secara langsung yang bersifat kontekstual

4) Tujuan pendidikan adalah mengajar siswa berpikir secara rasional, sehingga mereka menjadi serdas, dan mampu member kontribusi pada masyarakat.

5) Di sekolah para siswa mempelajari nilai-nilai personal dan juga nilai-nilai social.

6) Manusia berada dalam suatu keadaan yang berubah secara konstan, dan pendidikan memungkinkan masa depan yang lebih baik dibandingkan dengan masa lalu.

Menurut pandangan filsafat progresivisme belajar adalah bukan proses penerimaan pengetahuan dari guru pada siswa, tetapi belajar merupakan pengalaman yang dilakukan secara aktif, baik aktif secara mental dalam bentuk aktivitas berpikir, maupun aktif secara fisik dalam bentuk kegiatan-kegiatan praktik dan melakukan langsung.

\section{2) Landasan Psikologis}

Interaksi pendidikan merupakan interaksi antar individu yang sangat komplek dan unik yang berlangsung dalam suatu konteks pedagogis. Interaksi pendidikan dipengaruhi oleh kondisi dan latar belakang individu yang berinteraksi yaitu kondisi dan latar belakang guru dan siswa. Menurut Sukmadinata (2003:32) dikemukakan bahwa:

"Psikologi pendidikan dibutuhkan untuk lebih memahami situasi pendidikan, interaksi gurudengan siswa, kemampuan, perkembangan, karakteristik dan factor-faktor yang melatarbelakangi perilaku siswa dan perilaku guru, proses belajar, pengajaran, pembelajaran, bimbingan, evaluasi, pengukuran, dan lain-lain."

Jadi jelas bahwa dalam pendidikan dibutuhkan pemahaman secara menyeluruh terhadap kondisi siswa, sehingga proses pembelajran dilakukan pada siswa sesuai dengan tingkat perkembangan, kemampuan dan kebutuhan siswa. Dengan demikian dalam proses pendidikan diperlukan pemahaman 
psikologi sebagai landasan pelaksanaan pendidikan. Secara garis besar dikenal ada tiga rumpun besar teori psikologi yaitu: teori disiplin mental, behaviorisme, dan cognitive gestalt-field.

\section{b. Pengertian pembelajaran berorientasi siswa}

Penerapan pembelajaran yang mengaktifkan siswa dapat dilakukan melalui pengembangan berbagai keterampilan belajar esensial secara efektif antara lain sebagai berikut: (1) berkomunikasi lisan dan tertulis secara efektif, (2) berpikir logis, kritis, dan kreatif, (3) rasa ingin tahu, (4) penguasaan teknologi dan informasi, (5) pengembangan personal dan social, dan (6) belajar mandiri.

Jadi, pembelajaran bukanlah komunikasi satu arah (one way communication) transformasi dari gurukepada siswa. Melaikan harus berupa komunikasi timbal balik secara interaktif antara siswa dengan guru.

Melihat pada karakteristik yang dimiliki pembelajaran yang berorientasi pada aktivitas siswa (PBAS), maka, pembelajaran seperti inilah yang dipelukan dan relevan dengan kondisi sekarang serta sangat memungkinkan dapat meningkatkan hasil belajar siswa. Sanjaya (2008:137) mengemukakan bahwa, “PBAS dapat dipandang sebagai suatu pendekatan dalam pembelajaran yang menekankan pada aktivitas siswa secara optimal untuk memperoleh hasil belajar berupa perpaduan antara aspek kognitif, afektif dan psikomotor secara seimbang. " selanjutnya Sanjaya (2006:136) mengatakan bahwa:

"dari konsep tersebut ada dua hal yang harus dipahami, yaitu: pertama, dipandang dari sisi proses pembelajaran, PBAS menekankan kepada aktivitas siswa secara optimal. Artinya PBAS menghendaki keseimbangan antara aktivitas fisik, mental, termasuk emosional dan aktivitas intelektual. Kedua, dipandang dari sisi hasil belajar, PBAS menghendaki hasil belajar yang seimbang dan terpadu antara kemampuan intelektual (kognitif), dan afektif (psikomotor)". 


\section{c. Asumsi yang mendasari PBAS}

Standart proses satuan pendidikan yang tertuang dalam Permendiknas Nomor 41 Tahun 2007 mengamanahkan bahwa "Pembelajaran didesain untuk membuat siswa aktif belajar melalui kebiatan eksplorasi, elaborasi, dan konfirmasi". Artinya pembelajaran yang efektif adalah pembelajaran yang menekankan dan berorientasi pada aktifitas siswa. Ada beberapa asumsi yang mendasari Pembelajaran Berorietasi Aktivitas Siswa (PBAS) yaitu:

1) Asumsi Filosofis tentang Pendidikan

Pendidikan bukan hanya mengembangkan intelektual saja, tetapi mengembangkan seluruh potensi yang dimiliki oleh siswa. Pendidikan merupakan usaha sadar untuk mengembangkan manusia menuju kedewasaan, baik kedewasaan intelektual, sosial, maupun kedewasaan moral. Pendidikan bertugas mengembangkan seluruh potensi siswa. Pengembangan potensi manusia, berlangsung sepanjang hayat, keseimbangan dengan kemampuan dan tingkat perkembangan siswa, keseimbangan antara kebebasan subjek didik dan kewibawaan guru, peningkatan kualitas hidup manusia.

2) Asumsi tentang Siswa Sebagai Subjek Pendidikan

Siswa sebagai subjek pendidikan yang sedang dalam tahap perkembangan. Artinya siswa diposisikan sebagai manusia yang sedang dalam tahap perkembangan dengan karakteristik dan potensi yang unik, hedrogen, aktif, dinamis, dan memiliki motivasi untuk memenuhi kebutuhannya. Asumsi ini memberikan gambaran bahwa siswa adalah subjek yang memiliki potensi sehingga proses pembelajaran seharusnya diarahkan untuk mengembangkas seluruh potensi yang dimiliki siswa.

3) Asumsi tentang Guru

Guru bertanggung jawab mencptakan susasana yang memungkinkan siswa dapat belajar dengan baik. Artinya guru arus bertanggung jawab atas tercapainya hasil belajar siswa, guru memiliki kemampuan professional dalam mengajar, kode etik keguruan, berperan sebagai sumber belajar, mediator, dan fasilitator belajar serta pemimpin dalam belajar yang memungkinkan 
terciptanya kondisi yang baik bagi siswa dalam belajar. Filosofi mengajar yang baik adalah bukan sekedar mentransfer pengetahuan (transfer of knowledge) kepada siswa, tetapi bagaimana membantu siswasupaya dapat belajar (learn how to learn).

4) Asumsi yang berkaitan dengan proses pembelajaran

Proses belajar akan terjadi bila siswa berteraksi secara aktif dengan lingkungan belajrnya. Artinya proses pembelajaran direncanakan dan dilaksanakan sebagai susatu system, proses belajar akan terjadi apabila siswa berinteraksi dengan lingkungan yang dirancang dan disiapkan oleh guru, dan lebih efektif bila menggunakan metode, strategi, pendekatan, dan model pembelajaran yang tepat dan berdaya guna, pemebelajaran member penekanan oada proses dan produk secara proporsional dan inti dari pembelajaran adalah adanya aktvitas belajar siswa secara aktif, kreatif, dan bermakna.

\section{d. Peran Guru Dalam Penerapan Pembelajaran Berorietasi Aktivitas Siswa}

Pelaksanaan pembelajaran berorientasi aktivitas siswa memposisikan guru dan siswa sama-sama sebagai subjek dalam kegiatan belajar, hanya beda peran dan tugasnya. Artinya dengan PBAS tidak berarti siswa dibuat aktif menggantikan peran guru, sehingga guru tidakperlu memainkan perannya dalam pembelajaran. Tetapi aktivitas belajar siswa diciptakan dan dikondisikan oleh guru sebagai mediator dan fasilitator belajar siswa. Dengan posisi samasama sebagai subjek belajar, siswa dapat mempelajari materi pembelajaran secara aktif dan langsung memaikan perannya dalam setting kontekstual. Artinya siswa belajar sesuatu sebagai pengalaman langsung dan hasil dari pengalaman tersebut akan menjadi individu yang memiliki kepribadian dan sikap positif serta keterampilan yang dapat menunjang pada kehidupan mandiri di masyarakat.

Menurut Sanjaya (2008:139) ada enam tugas yang harus dilakukan oleh guru dalam mendesain pembelajaran berorientasi aktivitas siswa, yaitu: (1) mengemukakan berbagai alternative tujuan pembelajaran yang harus dicapai 
sebelum kegiatan pembelajaran dimulai, (2) menyusun tugas-tugas belajar bersama siswa, (3) member informasi tentang kegiatan pembelajaran yang akan dilakukan, (4) memberikan bantuan dan pelayanan kepada siswa yang memrlukannya, (5) memberikan motivasi, mendorong siswa untu belajar, membimbing dan lain sebagainya melalui pengajuan pertanyaan-pertanyaa, dan (6) membantu siswa dalam menarik suatu kesimpulan kegiatan pembelajaran.

\section{e. Penerapan PBAS dalam Pembelajaran}

Kriteria penerapan PBAS dalam proses pembelajaran. Kriteri itu adalah bagaimana keterlibatan siswa dalam perencanaan pembelajaran, proses pembelajaran, dan evaluasi hasil pembelajaran. Semakin banyak keterlibatan siswa dalam ketiga aspek itu, maka semakin menunjukkan kadar PBAS dalam pembelajaran.

1) Keterlibatan siswa dalam proses perencanaan meliputi:

a) Perumusan tujuan pembelajaran. Idealnya dalam menetapkan tujuan pembelajaran seorang guru melibatkan siswa. Hal ini dilakukan karena konten pembelajaran berisi kemampuan atau komptensi dan pengalaman-pengalaman siswa yang akan dikembangkan dalam kegiatan pembelajaran harus sesuai dengan kebutuhan, kemampuan, dan tugastugas perkembangan siswa.

b) Penyusunan rancangan pembelajaran. Pada penyusunan RPP seorang guru harus melibatkan siswa, hal ini dilakukan agar RPP yaqng dibuat oleh guru dapat diterima dan sesuai dengan kebutuhan belajar siswa.

c) Memilih dan menetukan sumber belajar. Dalam memilih dan menentukan sumberbelajar, guru harus melibatkan siswa, yaitu dengan cara melibatkan siswa untuk mencari dan menemukan bahan serta sumber yang dibutuhkan siswa melalui penugasan dan pembuatana makalah dalam kegiatan pembelajaran.

d) Menentuakan dan mengadakan media pembelajaran yang akan digunakan. Siswa memiliki interest yang sangat berbeda-beda, yaitu ada 
yang auditif (senang mendengarkan), visual (senang melihat), dan kinestetik (senang melakukan), untuk itu agar menyentuh semua interest tersebut guru harus menggunakan multimedia yang melibatkan siswa.

2) Keterlibatan siswa dalam proses pembelajaran, meliputi:

a) Kegiatan fisik, mental, intelektual. Tujuan yang ingin dicapai dalam proses pembelajaran adalah pencapaian kompetensi yang meliputi kompetensi akademik, sosial dan vokasional, atau kalau meminjam istilah Bloom yaitu ranah kognitif, afektif, dan psikomotorik.

b) Kegiatan eksperimental. Dalam kegiatan eksperimen seorang guru harus banyak melibatkan siswa baik melalui kegiatan observasi, melakukan langsung di laboratorium atau di lapangan sampai pada pembuatan laporan untuk dipresentasikan.

c) Keinginan siswa untuk menciptakan iklim belajar yang kondusif.

d) Keterlibatan siswa untuk mencari dan memamfaatkan sumber belajar yang ada. Sumber belajar saat ini sangat tidak terbatas apalagi dengan adanya computer, internet, dan media cetak, sehingga guru harus mampu memamfaatkan peluang yang baik ini.

e) Adanya interaksi multiarah, yaitu interaksi siswa dengan siswa, dan interaksi siswa dengan guru.

3) Keterlibatan siswa dalam proses evaluasi pembelajaran, dapat meliputi:

a) Mengevaluasi sendiri hasil pembelajaran yang telah dilakukan.

b) Melaksanakan kegiatan semacam tes dan tugas-tugas yang dikerjakannya baik secara terstruktur maupun tugas mandiriyang diberikan guru.

c) Menyusun laporan hasil belajar baik secara tertulis maupun lisan.

\section{f. Faktor-Faktor yang Mempengaruhi Keberhasilan PBAS}


Pelaksanaan pembelajaran berorientasi siswa akan berhasil dengan baik apabila didukung oleh beberapa hal di antaranya adalah factor kemampuan guru, sarana prasarana belajar, dan lingkungan belajar.

1) Kemampuan Guru

Guru merupakan faktor utama dalam pembelajaran, meskipun pembelajaran tersebut pembelajaran berorientasi aktivitas siswa (PBAS). Hanya peran guru tersebut yang membedakan pada setiap pendekatan pembelajaran yang digunakan. Pada pembelajaran berorientasi aktivitas siswa, guru berperan sebagai subjek, dan siswa pun berperan sebagai subjek dalam belajar.

2) Sarana dan prsarana belajar

Untuk mendukung kegiatan pembelajaran berorientasi aktivitas siswa agar berhasil dengan baik memerlukan dukungan fasilitas atau sarana dan prasarana yang memadai seperti: (1) ruang kelas yang memadai untuk terjadinya proses pembelajaran yang menimbulkan aktivitas siswa, yaitu ruang kelas yang memiliki ukuran ideal dengan jumlah siswa, pentilasi yang cukup, jauh dari kegaduhan, serta memungkinkan setting tempat duduk siswa untuk ditata secara dinamis sesuai dengan kebutuhan pembelajaran aktif; (2) tersedianya berbagai fasilitas media dan sumber belajar, seperti flip chart, papan planel, buku, majalah, surat kabar, bulletin, media radio, OHP, CD interaktif, telivisi, film slide, video, computer termasuk jaringan internet.

3) Lingkungan belajar

Di samping factor guru dan sarana-prasarana, keberhasilan pembelajaran berorientasi aktivitas siswa perlu ditunjang oleh faktor lingkungan belajar yang kondusif untuk terjadinya proses belajar yang aktif dan menantang. Lingkungan belajar yang dimaksud meliputi lingkungan fisik dan lingkungan psikologis.

\section{Mengaktifkan siswa melalui pendekatan dan model pembelajaran}

Ada banyak macam pembelajaran kolaboratif yang pernah dikembangkan oleh para ahli maupun praktisi pendidikan, teristimewa oleh para ahli student team learning 
pada John Hopkins University. Tetapi hanya sekitar sepuluh macam yang mendapatkan perhatian secara luas, yaitu

\section{a. Learning Together}

Pembentukan kelompok-kelompok di kelas beranggotakan siswa-siswa yang beragam kemampuannya. Tiap kelompok bekrja sama untuk menyelesaikan tugas yang diberikan oleh guru. Satu kelompok hanya menerima dan mengerjakan satu set lembar tugas. Penilaian pada hasil kerja kelompok.

\section{b. Teams-Games-Tournament (TGT)}

Setelah belajar bersama kelompok sendiri, para anggota suatu kelompok akan berlomba dengan anggota kelompok lain sesuai dengan tingkat kemampuan masing-masing. Penilaian didsarkan jumlah nilai yang diperoleh kelompok.

\section{c. Group Investigation (GI)}

Semua anggota kelompok dituntut untuk merencanakan suatu penelitian berserta perencanaan pemecahan masalah yang dihadapi. Kelompok menentukan apa saja yang akan dikerjakan dan siapa saja yang akan melaksanakannya.

\section{d. Academic-Constructive Controversy (AC)}

Setiap anggota kelompok dituntut kemampuannya untuk berada dalam situasi komflik intelektual yang dikembangkan berdasarkan hasil belajar masingmasing, baik bersama anggota sekelompok maupun dengan anggota kelompok lain. Kegiatan pembelajaran ini mengutamakan pencapaian dan pengembangan kualitas pemecahan masalah, pemikiran kritis, pertimbangan, hubungan antarpribadi, kesehatan psikis dan kesehatan keselarasan. Penilaian didasarkan pada kemampuan setiap anggota maupun kelompok mempertahankan posisi yang dipilihnya.

\section{e. Jigsaw Proscedure (JP)}

Dalam bentuk pembelajaran ini, anggota suatu kelompok diberi tugasyang berbdea-beda tentang suatu pokok bahasan. Agar setiap anggota dapat memahami keseluruhan pokok bahasan, tes diberikan dengan maetri yang menyeluruh. Penilaian didasarkan pada rata-rata skor perkelompok. 


\section{f. Student Team Achievement Divisions (STAD)}

Para siswa dalam suatu kelas dibagi menjadi beberapa kelompok kecil. Anggotaanggota bagi setiap kelompok saling belajar dan membelajarkan sesamanya. Fokusnya adalah keberhasilan seorang akan berpengaruh terhadap keberhasilan kelompok dan demikian pula keberhasilan kelompok akan berpengaruh terhadap keberhasilan individu siswa. Penilaian didasarkan pada pencapaian hasil belajar individual maupun kelompok.

\section{g. Complex instruction (CI)}

Metode pembelajaran ini menekankan pelaksanaan suatu proyek yang berorientasipada penemuan, khususnya dalam bidang sains, matematika, dan pengetahuan social. Fokusnya adalah menumbuhkembangkan ketertarikan semua anggota kelompok terhadap pokok bahasan. Metode ini umumnya digunakan dalam pembelajaran yang bersifat bilingual (menggunakan dua bahasa) dan di antara para siswa yang sangat heterogen. Penilaian didasarkan pada proses dan hasil kerja kelompok.

\section{h. Team accelerated instruction (TAI)}

Bentuk pembelajaran ini merupakan kombinasi antara pembelajaran kooperatif/kolaboratif dengan pembelajaran individual. Secara bertahap, setiap anggota kelompok diberi soal-soal yang harus mereka kerjakan sendiri terlebih dulu. Setelah itu dilaksanakan penilaian bersama-sama dalam kelompok. Jika soal tahap pertama telah diselesaikan dengan benar, setiap siswa mengerjakan soal-soal tahap berikutnya. Namun, jika seorang siswa belum dapat menyelesaikan soal tahap pertama dengan benar, ia harus menyelesaikan soal lain pada tahap yang sama. Setiap tahapan soal disusun berdasarkan tingkat kesukaran soal. Penilaian didasarkan pada hasil belajar individual maupun kelompok.

\section{i. Cooperative learning structures (CLS)}

Dalam pembelajaran ini setiap kelompok dibentuk dengan anggota dua siswa (berpasangan). Seorang siswa bertindak sebagai tutor dan yang lain menjadi tutee. Tutor mengajukan pertanyaan yang harus dijawab oleh tutee. Bila 
jawaban tutee benar, ia memperoleh poin atau skor yang telah ditetapkan terlebih dulu. Dalam selang waktu yang juga telah ditetapkan sebelumnya, kedua siswa yang saling berpasangan itu berganti peran.

\section{j. Cooperative integrated reading and composition (CIRC)}

Model pembelajaran ini mirip dengan TAI. Sesuai namanya, model pembelajaran ini menekankan pembelajaran membaca, menulis, dan tata bahasa. Dalam pembelajaran ini, para siswa saling menilai kemampuan membaca, menulis, dan tata bahasa, baik secara tertulis maupun lisan di dalam kelompoknya (Ruhcitra,2008).

\section{Penutup}

Pendekatan dapat diartikan sebagai titik tolak atau sudut pandang kita terhadap proses pembelajaran. Terdapat dua pendekatan dalam pembelajaran, yaitu pendekatan yang berpusat pada guru (teacher-centered approaches) dan pendekatan yang berpusat pada siswa (student-centered approaches), pendekatan yang berpusat pada guru menurunkan strategi pembelajaran langsung (direct instruction), pembelajaran deduktif atau pembelajaran ekspositori. Sedangkan, pendekatan pembelajaran yang berpusat pada siswa menurunkan strategi pembelajaran inquiri dan discoveri serta pembelajaran induktis.

Setiap model pembelajaran ada keunggulan dan kelemahannya, untuk mengatasi kelemahan dari sebuah model pembelajaran bergantung kepada bagaimana guru mengimplementasikan model pembelajaran tersebut dalam bentuk kemasan yang lebih efektif dan efisien. Hasil ujicoba sementara menunjukkan bahwa pembelajaran dengan model pembelajaran yang mengaktifkan siswa dapat diterapkan di sekolah dasar sebagai alternatif pembelajaran dengan keunggulan antara lain: dapat meningkatkan perolehan hasil belajar; dapat memotivasi anak; anak lebih aktif dan kreatif; hubungan guru dengan anak cukup akrab sehingga siswa lebih berani bertanya.

Pendekatan dan model apapun yang digunakan dalam kegiatan pembelajaran, diharapkan selalu mendudukkan siswa sebagai pusat perhatian dan 
perlakuan. Peranan guru dalam pembentukan pola kegiatan pembelajaran di kelas bukan ditentukan oleh didaktik metodik " apa yang akan dipelajari" saja, melainkan pada "bagaimana menyediakan dan memperkaya pengalaman belajar anak". Pengalaman belajar anak diperoleh melalui serangkaian kegiatan untuk mengeksplorasi secara 


\section{DAFTAR PUSTAKA}

Ali Mudlofir, Evi Fatmatur Rusydiyah, I, 2016. Desain Pembelajaran Inovatif (dari teori ke praktik). Jakarta: Raja Grafindo.

Abdulhak, I, 2001. Komunikasi Pembelajaran: Pendekatan Konvergensi Dalam Peningkatan Kualitas Dan Efektifitas Pembelajaran. Bandung: UPI.

Ardhana, W.2001. Reformasi Pembelajaran Menghadapi Abad Pengetahuan. Makalah disamapikan dalam kuliah perdana Program S2 Teknologi Pembelajaran, Unepa di Gresik.

Ambimanyu. 1984. Keterampilan membuka dan menutup pembelajaran, Jakarta: Ditjen Dikti.

Jurnal, Pendidikan dan Pembelajaran, Vol. 20, Nomor 1, April 2013

Jurnal, Pendidikan Kimia (JPK), Vol. 1 Tahun 2012, Program StudiPendidikan Kimia Universitas Negeri Malang.

Arifi, 1995. Kapita Selekta Pendidikan (Islam dan Umum). Jakarta: Bumi Aksara, Cet. Ke-3

Arikunto, Suharsini. 1980. Manajemen Pengajaran, Yogyakarta: Rineka Cipt.

Kellen Roy. Effective Teaching Strategis Lesson From Research And Practice. South Melbourne, Vic.: Thomson Social Science Press, 2007

Santyasa, I Wayan. 2006. Pembelajaran Inovatif: Model Kolaboratif, Basis Proyek, dan Orientasi NOS. Available at: (htt: //www.freewebs.com/santyasa/PDF_ files/ Collaborative_model_Project_Based_dan_Orientasi_NOS.pdf.

Sanjaya, Wina. 2008. Strategi Pembelajaran: Berorientasi Standar Proses Pendidikan . Jakarta: Kencana Prenada Media Group.

Semiawan, C. 1997. Pendekatan Keterampilan Proses. Jakarta: PT Gramedia

Silberman, M. 1996. Acktive Learning. Pustaka Insan Madani.

Sukmadinata, nana S. 2003. Landasan Psikologi Proses Pendidikan. Bandung: Remaja Rosdakarya. 
Pendekatan dan Model Pembelajaran yang Mengaktifkan Siswa 